\title{
Agronomic evaluation of cowpea as a function of weed control with herbicides and different combinations ${ }^{1}$
}

\author{
Avaliação agronômica do feijão-caupi em função do controle de invasoras com \\ diferentes herbicidas e combinações
}

\author{
Wando Wilson de Oliveira Souza ${ }^{2}$, Alexandre Bosco de Oliveira ${ }^{3 *}$, Alek Sandro Dutra ${ }^{3}$, Renato Leandro Costa \\ Nunes $^{2}$ and Robson Assunção Cavalcante ${ }^{4}$
}

\begin{abstract}
Cultivation of the cowpea is important in various regions of Brazil, but competition from weeds is one of the factors which limit productivity. The aim of this study therefore was to evaluate the pre-plant selectivity and efficiency of different herbicides, and combinations of herbicides, in the cowpea [Vigna unguiculata (L.) Walp.]. An experiment was carried out in a randomised block design, in lots split over time and with three replications, using a $4 \times 7$ factorial scheme, where the treatments consisted of: glyphosate, glyphosate + imazethapyr, glyphosate + flumioxazin, glyphosate + imazethapyr + flumioxazin, glyphosate + ready mix (imazethapyr \& flumioxazin), and two control treatments (one with no weeding and one with manual weeding). The treatments were evaluated in combination with four different sowing times, i.e. immediately after application of the herbicides, and at five, ten and fifteen days after application (DAA). The combination of glyphosate + flumioxazin at 15 DAA, gave the highest mean productivity, $1,105.32 \mathrm{~kg} \mathrm{ha}^{-1}$, followed by manual weeding with $1,027.37 \mathrm{~kg} \mathrm{ha}^{-1}$. The herbicide mixtures of glyphosate + imazethapyr + flumioxazin caused phyto-toxicity in the cowpea crop, limiting the production components. The best strategies for weed control in this crop are manual weeding with seeding at 10 DAA, as well as the application of a glyphosate + flumioxazin mixture with seeding at 15 DAA.
\end{abstract}

Key words: Vigna unguiculata (L.) Walp. Chemical control. Competition from weeds.

\begin{abstract}
RESUMO - O cultivo do feijão-caupi tem se destacado em várias regiões brasileiras, mas a competição com as plantas daninhas é um dos fatores que limita a produtividade. Assim, objetivou-se avaliar a seletividade e eficácia de diferentes herbicidas e suas combinações em pré-plantio na cultura do feijão-caupi [Vigna unguiculata (L.) Walp.]. Para tanto, foi conduzido um experimento em blocos casualizados, com parcelas subdivididas no tempo, e três repetições, em arranjo fatorial $4 \times 7$, cujos tratamentos consistiram de: glyphosate; glyphosate + imazethapyr; glyphosate + flumioxazin; glyphosate + imazethapyr + flumioxazin; glyphosate + mistura pronta (imazethapyr \& flumioxazin); e dois tratamentos controle (um sem capina e um com capina manual). Avaliados em combinação com quatro épocas de semeaduras diferentes, isto é, imediatamente após aplicação dos herbicidas, aos cinco, dez e quinze dias após aplicação (DAA). A combinação glyphosate + flumioxazin aos 15 DAA, foi a que obteve a maior média de produtividade $1.105,32 \mathrm{~kg} \mathrm{ha}^{-1}$, seguido da capina manual 1.027,37 $\mathrm{kg} \mathrm{ha}^{-1}$. As misturas dos herbicidas glyphosate + imazethapyr + flumioxazin causaram fitotoxidez na cultura do feijão-caupi, promovendo limitações nos componentes de produção. As melhores estratégias de controle das plantas daninhas para esta cultura são a capina manual e semeadura aos 10 DAA, bem como a aplicação da mistura glyphosate + flumioxazin e semeadura 15 DAA.
\end{abstract}

Palavras-chave: Vigna unguiculata (L.) Walp. Controle químico. Matocompetição.

\footnotetext{
* Autor para correspondência

DOI: $10.5935 / 1806-6690.20160081$

${ }^{1}$ Recebido para publicação em 08/09/2015; aprovado em 11/02/2016

Trabalho de Conclusão de Curso do primeiro autor apresentada no curso de Agronomia da Universidade Federal do Ceará

${ }^{2}$ Departamento de Fitotecnia, Universidade Federal do Ceará, CCA/UFC, Campus do Pici, Fortaleza-CE, Brasil, wandowilson@gmail.com, renatoleandro.ce@hotmail.com

${ }^{3}$ Departamento de Fitotecnia,, Universidade Federal do Ceará, CCA/UFC, Campus do Pici, Fortaleza-CE, Brasil, alexandrebosco@ufc.br, alekdutra@ufc.br

${ }^{4}$ Nufarm, Maracanaú-CE, Brasil, robson.cavalcante@br.nufarm.com
} 


\section{INTRODUCTION}

The cowpea [Vigna unguiculata (L.) Walp.] is a species of great importance for human consumption due to its nutritional value. It is also a good source of protein (on average 23 to $25 \%$ ). It is grown particularly in the north and northeast of Brazil, where it generates employment and income in rural and urban areas (LIMA et al., 2007; SANTOS et al., 2014); it also contains all the essential amino acids (carbohydrates, vitamins and minerals).

Interference from weeds is an important factor, and should be taken into account in cultivating the cowpea. Some farmers however neglect such control, which impairs the mean productivity of the crop, since, as reported in the literature, this interference may result in a significant reduction in grain yield (FREITAS et al., 2009; OLIVEIRA et al., 2010; VIDAL et al., 2008).

With expansion of the areas cultivated with cowpea, manual weeding has changed from being the main method, to complementing methods of chemical control. Silva, Vivian and Oliveira Junior (2007) report several advantages in using herbicides for weed control, such as being less labor-dependent, being efficient even during rainy periods, properly controlling weeds in the crop row, not damaging the root system of the crop, making it possible to use minimum tillage or direct planting, and being efficient in preventing vegetative propagation.

Use of this method in the cowpea is restricted by the limited number of products registered with the Ministry of Agriculture Livestock and Supply (MAPA), hampering the recommendation and use of such products (SILVA; ALBERTINO, 2009). In addition, there is still little knowledge of the tolerance of cowpea varieties to herbicides, due to the small amount of research being conducted in the area. It should be noted that the selectivity of herbicides depends on the physiological and genetic characteristics of the species or cultivar, on the herbicide employed and on the environmental conditions (FONTES; GONÇALVES; MORAIS, 2010; FONTES; OLIVEIRA; GONÇALVES, 2013; LINHARES et al., 2014; MONTEIRO et al., 2012; PROCÓPIO et al., 2009; SILVA et al., 2014).

The weeds present in areas used for agricultural crops are usually found to be very heterogeneous on the ground. The simultaneous or sequential use of two or more herbicides has therefore been increasingly employed in agriculture, and represents an advance in weed-control strategies (GRESSEL, 1990). To this effect, a mixture of herbicides in the sprayer tank can offer a number of important benefits when compared to the separate application of a product. For Machado et al. (2006), among the advantages seen when working with such mixtures, of importance are the number of species being controlled, the better control of certain species, a reduction in spraying costs and the possibility of reducing the recommended dose, thereby resulting in a reduction in residues in the soil and toxicity to the culture.

For these reasons, the aim of this work was to evaluate the selectivity of cowpea cv. Setentão to different herbicides and their combination.

\section{MATERIAL AND METHODS}

The experiment was carried out from July to November 2014 in the city of Horizonte in the State of Ceará, Brazil (CE), located at $04^{\circ} 05^{\prime} 09^{\prime \prime} \mathrm{S}$ and $38^{\circ} 39^{\prime} 05^{\prime \prime} \mathrm{W}$ at an altitude of $65 \mathrm{~m}$. The climate in the region is hot tropical mild semi-arid, with rainfall from January to May.

The results of the soil analysis, made at a depth of 0-20 cm, was as follows: $\mathrm{pH}$ (in water) $=6.4 ; \mathrm{H}+$ $\mathrm{Al}=1.16 \mathrm{cmol}_{\mathrm{c}} \mathrm{kg}$; absorbable $\mathrm{P}=5 \mathrm{mg} \mathrm{kg} ; \mathrm{Ca}=1.00$ $\mathrm{cmol}_{\mathrm{c}} \mathrm{kg} ; \mathrm{Mg}=0.80 \mathrm{cmol}_{\mathrm{c}} \mathrm{kg} ; \mathrm{K}=0.18 \mathrm{cmol}_{\mathrm{c}} \mathrm{kg} ; \mathrm{S}=$ $2.1 \mathrm{cmol}_{\mathrm{c}} \mathrm{kg} ; \mathrm{Na}=0.09 \mathrm{cmol}_{\mathrm{c}} / \mathrm{kg}$; Organic Matter $=$ $7.76 \mathrm{~g} \mathrm{~kg}$; Sum of Bases $(\mathrm{SB})=2.07 \mathrm{cmol}_{\mathrm{c}} \mathrm{kg}$; $\mathrm{CEC}=$ $2.22 \mathrm{cmol} \mathrm{kg}$. Soil preparation consisted of plowing and harrowing. Base fertilization was carried out according to the above chemical soil analysis, using $454 \mathrm{~kg} \mathrm{ha}^{-1}$ urea, single superphosphate and potassium chloride, in an NPK formulation 06-24-12 (FREITAS et al., 2013).

The Setentão cultivar was used for sowing, with three seeds being distributed per hole at a depth of $3 \mathrm{~cm}$. The plants were then thinned so as to obtain an estimated density of 71,000 plants per hectare. The experiment consisted of a total of 84 lots and sub-lots, with the different herbicides distributed over the lots, and sowing dates over the sub-lots. Each experimental lot consisted of four rows, $5 \mathrm{~m}$ in length, spaced $0.80 \mathrm{~m}$ between rows and $0.30 \mathrm{~m}$ between plants, giving a total area of $16 \mathrm{~m}^{2}$. However, to analyze the variables, only the three central rows of each lot were used, resulting in a usable area of $12 \mathrm{~m}^{2}$. The plants were irrigated by means of a microsprinkler system.

Two management strategies were evaluated, chemical control and manual weeding. Under the first management, five herbicides or mixtures were used, with manual weeding being tested under the latter, as well as an additional control to observe the damage caused by weed competition (no weeding) (Table 1). The modesof-action of the herbicides are EPSP Synthase inhibition (glyphosate), ALS inhibition (imazethapyr) and Protox inhibition (flumioxazin). The effect of the treatments 
Table 1 - List of herbicides with respective doses applied to the cowpea crop, Horizonte, CE, 2014

\begin{tabular}{lcc}
\hline Treatment & Concentration (ai) g kg or g L$^{-1}$ & Dose (cp) g or ml treatment \\
\hline T1 - Control (no weeding) & & \\
T2 - Control (manual weeding) & & \\
T3 - Glyphosate & 540 & 26.7 \\
T4 - Glyphosate+Imazethapyr & $540+106$ & $26.7+13.3$ \\
T5 - Glyphosate+Flumioxazin & $540+500\left({\left.\mathrm{~g} \cdot \mathrm{kg}^{-1}\right)}^{-1}\right.$ & $26.7+1.3(\mathrm{~g})$ \\
T6 - Glyphosate+Imazethapyr+Flumioxazin & $540+106+500\left({\left.\mathrm{~g} \cdot \mathrm{kg}^{-1}\right)}^{-1}\right.$ & $26.7+13.3+1.3(\mathrm{~g})$ \\
T7 - Glyphosate+Ready-Mix (Imazethapyr \& Flumioxazin) & $540+212+500$ & $26.7+6.7$ \\
\hline
\end{tabular}

ai - active ingredient; $\mathrm{cp}$ - commercial product

was evaluated in combination with four different sowing dates, i.e. immediately after application of the herbicide, and at five, ten and fifteen days after application (DAA).

Herbicide application was carried out on 16 August 2014, using the appropriate PPE and a back sprayer equipped with a $3 \mathrm{~m}$ spray bar of 6 Magno 11002 nozzles with regular fan-type jets spaced $50 \mathrm{~cm}$ apart, kept at a height of $50 \mathrm{~cm}$ from the target, under a pressure of $2 \mathrm{kgf} / \mathrm{m}^{2}$, and with a spray volume of $2 \mathrm{~L}_{\text {treatment }}{ }^{-1}$.

The control provided by the herbicides was measured by quantifying the species of weeds (number of individuals and dry weight) found in $1 \mathrm{~m}^{2}$ at three random points per lot. Phytotoxicity was evaluated by periodic visual observation of the cowpea plants.

At the end of the experiment four cowpea plants were collected randomly from the two central rows of each lot and the pods removed. Weed samples were taken using a $0.50 \mathrm{~m}$ sampling square $\left(0.25 \mathrm{~m}^{2}\right)$. Once collected, the plants were sent to the Production and Physiology Laboratory (CCA/UFC) to be dried in a forced circulation oven at a temperature of $70( \pm 3){ }^{\circ} \mathrm{C}$ to constant weight, in order for the dry weight to be determined. An evaluation was made of the number of plants, plant height, number of pods per plant, number of grains per pod, pod length, 100 -grain weight and productivity.

Data on the variables being studied were subjected to analysis of variance, and the mean values for the treatments were compared by Tukey's test at $5 \%$ probability. Statistical analysis was performed with the help of the ASSISTAT (7.7 beta) statistical software (SILVA; AZEVEDO, 2009).

\section{RESULTS AND DISCUSSION}

The main species of weeds identified in the experimental area are shown in Table 2. Among the species found, it can be seen that Panicum maximum Jacq. was the more predominant in the lots, i.e. its evolution was greatest in the cultivated area.

For the dry weight of the weeds, significant variation was found in the interaction between the factors time and treatment (Table 3). It can be seen that the treatments glyphosate + imazethapyr (T4) and glyphosate + imazethapyr + flumioxazin (T6), with sowing carried out 15 and 10 days after application (DAA) respectively, were not effective in controlling the weeds, even when compared to the control with no weeding (T1). Given that there are various factors which can affect the efficiency of herbicides, a reduction in the efficiency of these products may have been caused by the physicochemical properties or factors related to the technology of applying the two mixtures, or the characteristics of soil and climate at the experimental site.

Evaluating the crop stand, it was found that the herbicide glyphosate, and the glyphosate + imazethapyr combination at 5 and 0 DAA respectively, caused a reduction in the number of cowpea plants (Table 4). For plant height, the treatments which stand out are glyphosate + flumioxazin at 15 DAA, and glyphosate + imazethapyr + flumioxazin at 0 DAA, with higher mean values for this variable compared to the other products and mixtures. Such results help show that the phytotoxicity seen in some plants with these treatments did not irreversibly affect the crop, since over time the cowpea was able to maintain a good stand and satisfactory initial development. In another study of the pre-emergence application of a mixture of herbicides, Ishaya et al. (2008) reported similar behavior for the cowpea under application of the herbicides metolachlor and prometryn $(1250+$ $800 \mathrm{~g}$ ai ha- $\mathrm{ha}^{-1}$, noting that in plants of the SAMPEA7 variety of cowpea there was no negative effect on vigor, nor severe visual symptoms of phytotoxicity.

For dry matter production in the cowpea plants, it can be seen that there was a reduction under those treatments which included the application of glyphosate 
+ imazethapyr + flumioxazin, and of glyphosate + ReadyMix (imazethapyr \& flumioxazin) (Table 4). Corroborating the results of this study, Sikkema et al. (2006) reported that the application of pre-plant incorporated (PPI) imazethapyr in an area cultivated with the common bean (Phaseolus vulgaris L.) reduced plant height, shoot dry weight and grain productivity by 8,18 and $12 \%$ at a dose of $75 \mathrm{~g} \mathrm{ha}^{-1}$, and by 19,38 and $27 \%$ when the herbicide dose was $150 \mathrm{~g} \mathrm{ha}^{-1}$ respectively.

The results obtained in the present study therefore demonstrate some phytotoxicity caused by the mixture of glyphosate, imazethapyr and flumioxazin. This indicates an undesired effect from the use of a mixture of these three products on the cowpea crop, leading to a reduction in the production of plant biomass. Monteiro et al. (2012), evaluating selectivity in the cowpea to the herbicide s-metalochlor, also found a high degree of phytotoxicity, which completely inhibited crop growth. However, Procópio et al. (2009), using treatments based on fomesafen and fomesafen + imazethapyr, found no significant reduction in shoot dry weight in bean cultivars.

Table 2 - Weeds in the lots, Horizonte, CE, 2014

\begin{tabular}{|c|c|c|c|c|}
\hline \multirow{2}{*}{ Plant Species } & $0 \mathrm{DAA}$ & 5 DAA & $10 \mathrm{DAA}$ & $15 \mathrm{DAA}$ \\
\hline & \multicolumn{4}{|c|}{ - } \\
\hline Amaranthus deflexus L. & 4 & 8 & 24 & 21 \\
\hline Alternanthera tenella Colla. & 1 & 2 & 3 & 1 \\
\hline Bidens pilosa L. & 0 & 1 & 2 & 0 \\
\hline Commelina benghalensis L. & 1 & 0 & 0 & 0 \\
\hline Cyperus flavus (Vahl.) Nees. & 0 & 1 & 0 & 6 \\
\hline Chamaesyce hirta (L.) Milisp. & 0 & 0 & 3 & 0 \\
\hline Mimosa candollei R. Grether & 2 & 4 & 4 & 11 \\
\hline Sida glaziovii K. Shum & 0 & 0 & 0 & 1 \\
\hline Sida cordifolia $\mathrm{L}$. & 0 & 23 & 11 & 3 \\
\hline Mollugo verticillata $\mathrm{L}$. & 0 & 3 & 0 & 0 \\
\hline Brachiaria plantaginea (Link.) Hitchc & 8 & 11 & 1 & 4 \\
\hline Panicum maximum Jacq. & 236 & 453 & 335 & 266 \\
\hline Portulaca oleraceae L. & 3 & 1 & 0 & 0 \\
\hline Richardia scabra L. & 1 & 1 & 1 & 0 \\
\hline Spermacoce vereticillata $\mathrm{L}$. & 4 & 4 & 6 & 1 \\
\hline
\end{tabular}

Table 3 - Weed dry weight as found in the experiment, for herbicide and sowing date, Horizonte, CE, 2014

\begin{tabular}{|c|c|c|c|c|}
\hline \multirow{2}{*}{ Treatment } & $0 \mathrm{DAA}$ & $5 \mathrm{DAA}$ & $10 \mathrm{DAA}$ & 15 DAA \\
\hline & \multicolumn{4}{|c|}{---------------- Weed Dry Weight $(\mathrm{g})$-------------- } \\
\hline T1 - Control (no weeding) & $10 \mathrm{abA}$ & $13.3 \mathrm{abA}$ & $17.7 \mathrm{bA}$ & $7.3 \mathrm{bA}$ \\
\hline T2 - Control (manual weeding) & $7 \mathrm{bA}$ & $6.7 \mathrm{abA}$ & $6 \mathrm{bA}$ & $9.7 \mathrm{bA}$ \\
\hline T3 - Glyphosate & $13 \mathrm{abA}$ & $13 \mathrm{abA}$ & $5.3 \mathrm{bA}$ & $6.7 \mathrm{bA}$ \\
\hline T4 - Glyphosate+Imazethapyr & $5 \mathrm{bB}$ & $4.7 \mathrm{bB}$ & $13.3 \mathrm{bB}$ & $33.3 \mathrm{aA}$ \\
\hline T5 - Glyphosate+Flumioxazin & $23.3 \mathrm{aA}$ & $5.3 \mathrm{abB}$ & $5 \mathrm{bB}$ & $4 \mathrm{bB}$ \\
\hline T6 - Glyphosate+Imazethapyr+Flumioxazin & $4.7 \mathrm{bB}$ & $8.3 \mathrm{abB}$ & $33.3 \mathrm{aA}$ & $13.3 \mathrm{bB}$ \\
\hline T7 - Glyphosate+Ready-Mix (Imazethapyr \& Flumioxazin) & $5 \mathrm{bB}$ & $20 \mathrm{aA}$ & $4.7 \mathrm{bB}$ & $13.3 \mathrm{bAB}$ \\
\hline
\end{tabular}

Uppercase letters compare sowing date for each control strategy and lowercase letters compare control strategy for each sowing date. DAA - Days after application of the weed-control strategies 
Table 4 - Number of plants, plant height, dry weight and 100-grain weight in the cowpea, for different control strategies and sowing dates, Horizonte, CE, 2014

\begin{tabular}{|c|c|c|c|c|}
\hline \multirow{2}{*}{ Treatment } & 0 DAA & 5 DAA & $10 \mathrm{DAA}$ & $15 \mathrm{DAA}$ \\
\hline & \multicolumn{4}{|c|}{ - } \\
\hline T1 - Control (no weeding) & $25.33 \mathrm{aA}$ & 23.66 abA & $23 \mathrm{aA}$ & $24.33 \mathrm{aA}$ \\
\hline T2 - Control (manual weeding) & $28 \mathrm{aA}$ & $25 \mathrm{aA}$ & $17 \mathrm{bB}$ & $8.33 \mathrm{bC}$ \\
\hline T3 - Glyphosate & $10 \mathrm{cA}$ & $5 \mathrm{eB}$ & $7 \mathrm{cAB}$ & $7 \mathrm{bAB}$ \\
\hline T4 - Glyphosate+Imazethapyr & $4.66 \mathrm{dC}$ & $19 \mathrm{bcA}$ & $19 \mathrm{abA}$ & $10.66 \mathrm{bB}$ \\
\hline T5 - Glyphosate+Flumioxazin & $8.66 \mathrm{cdB}$ & $10.66 \mathrm{~dB}$ & $20 \mathrm{abA}$ & $21.33 \mathrm{aA}$ \\
\hline T6 - Glyphosate+Imazethapyr+Flumioxazin & $17.66 \mathrm{bA}$ & $17.33 \mathrm{cA}$ & $10 \mathrm{cB}$ & $6.66 \mathrm{bB}$ \\
\hline \multirow[t]{2}{*}{ T7 - Glyphosate+Ready-Mix(Imazethapyr \& Flumioxazin) } & $11 \mathrm{cA}$ & $11.66 \mathrm{dA}$ & $9.66 \mathrm{cA}$ & $7.66 \mathrm{bA}$ \\
\hline & \multicolumn{4}{|c|}{ - } \\
\hline T1 - Control (no weeding) & $31.56 \mathrm{bcD}$ & $40.7 \mathrm{aB}$ & $46.6 \mathrm{aA}$ & $36.23 \mathrm{bC}$ \\
\hline T2 - Control (manual weeding) & $34.3 \mathrm{bcA}$ & $32.23 \mathrm{bA}$ & $25.43 \mathrm{~dB}$ & $26.16 \mathrm{~dB}$ \\
\hline T3 - Glyphosate & $35.46 \mathrm{bAB}$ & $24.33 \mathrm{cC}$ & $37.46 \mathrm{bA}$ & $33.23 \mathrm{bcB}$ \\
\hline T4 - Glyphosate+Imazethapyr & $26.56 \mathrm{deB}$ & $26.8 \mathrm{cB}$ & $36.73 \mathrm{bA}$ & $33.56 \mathrm{bcA}$ \\
\hline T5 - Glyphosate+Flumioxazin & $30.5 \mathrm{cdB}$ & $27.7 \mathrm{bcB}$ & $30.36 \mathrm{cB}$ & $46.33 \mathrm{aA}$ \\
\hline T6 - Glyphosate+Imazethapyr+Flumioxazin & $42.46 \mathrm{aA}$ & $28.83 \mathrm{bcB}$ & $28.96 \mathrm{cdB}$ & $28.13 \mathrm{~dB}$ \\
\hline \multirow[t]{2}{*}{ T7 - Glyphosate+Ready-Mix (Imazethapyr \& Flumioxazin) } & $24.4 \mathrm{eB}$ & $27.06 \mathrm{cAB}$ & $30.06 \mathrm{cdA}$ & $30.16 \mathrm{cdA}$ \\
\hline & \multicolumn{4}{|c|}{ - - } \\
\hline T1 - Contro & $60 \mathrm{aAB}$ & $60 \mathrm{aAB}$ & $85 \mathrm{aA}$ & $53.33 \mathrm{aB}$ \\
\hline T2 - Control (manual weeding) & $56.66 \mathrm{abA}$ & $53.33 \mathrm{abA}$ & $46.66 \mathrm{bAB}$ & $20 \mathrm{aB}$ \\
\hline T3 - Glyphosate & $43.33 \mathrm{abA}$ & $26.66 \mathrm{abcA}$ & $31.66 \mathrm{bA}$ & $23.33 \mathrm{aA}$ \\
\hline T4 - Glyphosate+Imazethapyr & $43.33 \mathrm{abA}$ & $36.66 \mathrm{abcA}$ & $33.33 \mathrm{bA}$ & $43.33 \mathrm{aA}$ \\
\hline T5 - Glyphosate+Flumioxazin & $46.66 \mathrm{abA}$ & $46.66 \mathrm{abcA}$ & $50 \mathrm{bA}$ & $46.66 \mathrm{aA}$ \\
\hline T6 - Glyphosate+Imazethapyr+Flumioxazin & $53.33 \mathrm{abA}$ & $16.66 \mathrm{cB}$ & $20 \mathrm{bB}$ & $26.66 \mathrm{aAB}$ \\
\hline \multirow[t]{2}{*}{ T7 - Glyphosate+Ready-Mix (Imazethapyr \& Flumioxazin) } & $23.33 \mathrm{bA}$ & $20 \mathrm{bcA}$ & $36.66 \mathrm{bA}$ & $30 \mathrm{aA}$ \\
\hline & \multicolumn{4}{|c|}{ - } \\
\hline T1 - Control (no weeding) & $24.8 \mathrm{aA}$ & $24.83 \mathrm{aA}$ & $25.93 \mathrm{aA}$ & $26.7 \mathrm{aA}$ \\
\hline T2 - Control (manual weeding) & $25.63 \mathrm{aA}$ & $24.73 \mathrm{aA}$ & $23.06 \mathrm{aA}$ & $14.4 \mathrm{bB}$ \\
\hline T3 - Glyphosate & $24.3 \mathrm{aA}$ & $16.13 \mathrm{abAB}$ & $18.26 \mathrm{aAB}$ & $14.06 \mathrm{bB}$ \\
\hline T4 - Glyphosate+Imazethapyr & $16.93 \mathrm{aBC}$ & $16 \mathrm{abC}$ & $25.5 \mathrm{aA}$ & $24.46 \mathrm{aAB}$ \\
\hline T5 - Glyphosate+Flumioxazin & $24.56 \mathrm{aA}$ & $25.53 \mathrm{aA}$ & $25.53 \mathrm{aA}$ & $24.1 \mathrm{aA}$ \\
\hline T6 - Glyphosate+Imazethapyr+Flumioxazin & $24.66 \mathrm{aA}$ & $9.16 \mathrm{bB}$ & $22.86 \mathrm{aA}$ & $18.73 \mathrm{abA}$ \\
\hline T7 - Glyphosate+Ready-Mix (Imazethapyr \& Flumioxazin) & $18.5 \mathrm{aA}$ & $16.1 \mathrm{abA}$ & $22 \mathrm{aA}$ & $17.66 \mathrm{abA}$ \\
\hline
\end{tabular}

Uppercase letters compare sowing date for each control strategy and lowercase letters compare control strategy for each sowing date. DAA - Days after application of the weed-control strategies

Good mean values for 100-grain weight were found in the treatment with glyphosate + flumioxazin; these remained constant for all sowing dates, with no difference being seen due to this factor (Table 4). Good crop performance under this treatment seems to be directly related to the weed-control efficiency afforded by the mixture, which was responsible for significant reductions in the production of weed biomass in the area of cultivation (Table 3 ).

In Table 5, the productivity indicators displayed a negative effect in response to those treatments where 
a combination of the herbicides imazethapyr and flumioxazin was used, except for bean length at 10 DAA, where no significant difference was seen between the different herbicides under evaluation. The combinations of glyphosate + ready-mix (imazethapyr and flumioxazin) and glyphosate + imazethapyr + flumioxazin caused the greatest reduction in the number of pods.

The variable displaying the greatest difference between treatments was pod weight, with significantly lower values recorded for weed control involving the combinations of glyphosate + ready-mix (imazethapyr $\&$ flumioxazin) and glyphosate + imazethapyr + flumioxazin, as well as for the treatment employing glyphosate with hand weeding at 15 DAA (Table 5). Similarly, the number of grains per pod was adversely affected by the combination of glyphosate + flumioxazin + imazethapyr, as well as by the management with glyphosate at 15 DAA (Table 5). These results would indicate therefore, that reproductive development in the cowpea is impaired when weed control is carried out employing a mixture containing glyphosate, imazethapyr and flumioxazin.

Corroborating this experiment, Procópio et al. (2009) found that addition of the herbicide imazethapyr to fomesafen resulted in a reduction in grain productivity in the BRS Supremo, BRS Timbó and
BRS Vereda cultivars of cowpea. Freitas et al. (2010) in turn, found no harmful effects from a mixture of the herbicides imazamox + bentazon + fluazifop-p-butyl or imazethapyr + fluazifop-p-butyl, with no reduction in grain production. Therefore, given the behavior of the crop seen in the present study, it is believed that a mixture of those herbicides that inhibit the enzymes EPSP synthase (Glyphosate), ALS (Imazethapyr) and Protox (flumioxazin), may result in toxic chemical products, which are harmful to the full development of the cowpea crop.

Evaluating the weed-control strategies used in this experiment, as well as the two controls (no weeding and manual weeding), it can be seen that treatment five, where a combination of glyphosate + flumioxazin was applied at 15 DAA, achieved the greatest average for productivity, of $1,105.32 \mathrm{~kg} \mathrm{ha}^{-1}$, followed by manual weeding with $1,027.37 \mathrm{~kg} \mathrm{ha}^{-1}$ (Table 6).

The mean productivity obtained under treatment five (combination of glyphosate + flumioxazin at 15 DAA) was significantly superior to the $650 \mathrm{~kg} \mathrm{ha}^{-1}$ obtained by Rodrigues et al. (2014) with the Setentão cultivar under rainfed conditions in the interior of Ceará. Such productivity is even more significant when compared to the $548 \mathrm{~kg} \mathrm{ha}^{-1}$ reported by Araújo (2014) for irrigated cultivation of the same cultivar on the

Table 5 - Number of pods, pod length, pod weight and number of grains per pod in the cowpea, for different control strategies and sowing dates, Horizonte, CE, 2014

\begin{tabular}{|c|c|c|c|c|}
\hline \multirow{2}{*}{ Treatment } & 0 DAA & $5 \mathrm{DAA}$ & $10 \mathrm{DAA}$ & $15 \mathrm{DAA}$ \\
\hline & \multicolumn{4}{|c|}{ - Number of Pods -- } \\
\hline T1 - Control (no weeding) & $49 \mathrm{aA}$ & $38 \mathrm{abA}$ & $35 \mathrm{aA}$ & $29.3 \mathrm{abA}$ \\
\hline T2 - Control (manual weeding) & $33.3 \mathrm{abAB}$ & $55 \mathrm{aA}$ & $36 \mathrm{aAB}$ & $14.3 \mathrm{bB}$ \\
\hline T3 - Glyphosate & $26.3 \mathrm{abA}$ & $23.3 \mathrm{abA}$ & $13.6 \mathrm{aA}$ & $8.6 \mathrm{bA}$ \\
\hline T4 - Glyphosate+Imazethapyr & $26.6 \mathrm{abA}$ & $18.6 \mathrm{abA}$ & $16.3 \mathrm{aA}$ & $30 \mathrm{abA}$ \\
\hline T5 - Glyphosate+Flumioxazin & $33.6 \mathrm{abAB}$ & $39 \mathrm{abAB}$ & $17.6 \mathrm{aB}$ & $57.3 \mathrm{aA}$ \\
\hline T6 - Glyphosate+Imazethapyr +Flumioxazin & $47 \mathrm{aA}$ & $10.3 \mathrm{bB}$ & $9.6 \mathrm{aB}$ & $15.3 \mathrm{bB}$ \\
\hline \multirow[t]{2}{*}{ T7 - Glyphosate+Ready-Mix (Imazethapyr \& Flumioxazin) } & $6 \mathrm{bA}$ & $7.3 \mathrm{bA}$ & $15 \mathrm{aA}$ & $20.6 \mathrm{bA}$ \\
\hline & \multicolumn{4}{|c|}{ - } \\
\hline T1 - Control (no weeding) & $16.2 \mathrm{abA}$ & $16 \mathrm{aA}$ & $13.5 \mathrm{bB}$ & 15.9 abcA \\
\hline T2 - Control (manual weeding) & $16.4 \mathrm{abA}$ & $15.1 \mathrm{abAB}$ & $15.2 \mathrm{abAB}$ & $14.2 \mathrm{cdB}$ \\
\hline T3 - Glyphosate & $16.2 \mathrm{abA}$ & $16.8 \mathrm{aA}$ & $16.3 \mathrm{aA}$ & $12.1 \mathrm{~dB}$ \\
\hline T4 - Glyphosate+Imazethapyr & $15.8 \mathrm{abA}$ & $16.2 \mathrm{aA}$ & $16.3 \mathrm{aA}$ & $16.3 \mathrm{abcA}$ \\
\hline T5 - Glyphosate+Flumioxazin & $16 \mathrm{abA}$ & $16.8 \mathrm{aA}$ & $15.9 \mathrm{aA}$ & $16.7 \mathrm{abA}$ \\
\hline T6 - Glyphosate+Imazethapyr+Flumioxazin & $17 \mathrm{aA}$ & $16.5 \mathrm{aAB}$ & $15.6 \mathrm{abAB}$ & $14.6 \mathrm{bcB}$ \\
\hline T7 - Glyphosate+Ready-Mix (Imazethapyr \& Flumioxazin) & $14.5 \mathrm{bB}$ & $13.3 \mathrm{bB}$ & $14.9 \mathrm{abB}$ & $17.4 \mathrm{aA}$ \\
\hline
\end{tabular}


Continued Table 5

\begin{tabular}{|c|c|c|c|c|}
\hline & \multicolumn{4}{|c|}{ - } \\
\hline T1 - Control (no weeding) & $165 \mathrm{aA}$ & $160 \mathrm{abA}$ & $90 \mathrm{aB}$ & $110 \mathrm{bB}$ \\
\hline T2 - Control (manual weeding) & $130 \mathrm{abB}$ & $206.6 \mathrm{aA}$ & $86.3 \mathrm{aC}$ & $10 \mathrm{dD}$ \\
\hline T3 - Glyphosate & $117 \mathrm{abA}$ & $53.3 \mathrm{cBC}$ & $66.6 \mathrm{abB}$ & $20 \mathrm{dC}$ \\
\hline T4 - Glyphosate+Imazethapyr & $100 \mathrm{bcAB}$ & $113.3 \mathrm{bA}$ & $60 \mathrm{abB}$ & $100 \mathrm{bcAB}$ \\
\hline T5 - Glyphosate+Flumioxazin & $66.6 \mathrm{cC}$ & $175 \mathrm{aB}$ & $81.6 \mathrm{abC}$ & $235 \mathrm{aA}$ \\
\hline T6 - Glyphosate+Imazethapyr +Flumioxazin & $113.3 \mathrm{bcA}$ & $10 \mathrm{cB}$ & $36.6 \mathrm{bB}$ & $51.6 \mathrm{cdB}$ \\
\hline \multirow[t]{2}{*}{ T7 - Glyphosate+Ready-Mix (Imazethapyr \& Flumioxazin) } & $15 \mathrm{dA}$ & $13.3 \mathrm{cA}$ & $35 \mathrm{bA}$ & $43.3 \mathrm{dA}$ \\
\hline & \multicolumn{4}{|c|}{ 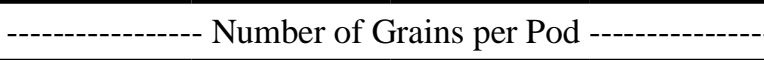 } \\
\hline T1 - Control (no weeding) & $11 \mathrm{aA}$ & $11.3 \mathrm{aA}$ & $9 \mathrm{aA}$ & $9.6 \mathrm{abA}$ \\
\hline $\mathrm{T} 2$ - Control (manual weeding) & $11.3 \mathrm{aA}$ & $11.3 \mathrm{aA}$ & $9.6 \mathrm{aAB}$ & $6.3 \mathrm{bB}$ \\
\hline T3 - Glyphosate & $10 \mathrm{aA}$ & $7 \mathrm{abAB}$ & $9 \mathrm{aAB}$ & $5.3 \mathrm{bB}$ \\
\hline T4 - Glyphosate+Imazethapyr & $7 \mathrm{aA}$ & $7.3 \mathrm{abA}$ & $9.6 \mathrm{aA}$ & $9.6 \mathrm{abA}$ \\
\hline T5 - Glyphosate+Flumioxazin & $10.3 \mathrm{aA}$ & $11.6 \mathrm{aA}$ & $10 \mathrm{aA}$ & $12 \mathrm{aA}$ \\
\hline T6 - Glyphosate+Imazethapyr +Flumioxazin & $11.6 \mathrm{aA}$ & $4.3 \mathrm{bB}$ & $10.3 \mathrm{aA}$ & $8.3 \mathrm{abAB}$ \\
\hline T7 - Glyphosate+Ready-Mix (Imazethapyr \& Flumioxazin) & $7 \mathrm{aA}$ & $6.3 \mathrm{bA}$ & $9.3 \mathrm{aA}$ & $8.3 \mathrm{abA}$ \\
\hline
\end{tabular}

Uppercase letters compare sowing date for each control strategy and lowercase letters compare control strategy for each sowing date. DAA - Days after application of the weed-control strategies

Table 6 - Productivity in the cowpea, for different control strategies and sowing dates, Horizonte, CE, 2014

\begin{tabular}{|c|c|c|c|c|}
\hline \multirow{2}{*}{ Treatment } & 0 DAA & 5 DAA & 10 DAA & 15 DAA \\
\hline & \multicolumn{4}{|c|}{---------------- Productivity (kg/ha) ------------- } \\
\hline T1 - Control (no weeding) & $891.1 \mathrm{aA}$ & $712.6 \mathrm{abA}$ & $544.5 \mathrm{bB}$ & $504.3 \mathrm{bB}$ \\
\hline T2 - Control (manual weeding) & $645.2 \mathrm{bB}$ & $1027.3 \mathrm{aA}$ & $534.6 \mathrm{bB}$ & $87 \mathrm{dC}$ \\
\hline T3 - Glyphosate & $426.5 \mathrm{cbA}$ & $175.6 \mathrm{cdB}$ & $149.6 \mathrm{cdBC}$ & $43.2 \mathrm{dC}$ \\
\hline T4 - Glyphosate+Imazethapyr & $210.6 \mathrm{cB}$ & $145.9 \mathrm{cdB}$ & $268.1 \mathrm{cB}$ & $472.5 \mathrm{cbA}$ \\
\hline T5 - Glyphosate+Flumioxazin & $569.3 \mathrm{bBC}$ & $773.9 \mathrm{abB}$ & $300.5 \mathrm{cC}$ & $1105.3 \mathrm{aA}$ \\
\hline T6 - Glyphosate+Imazethapyr+Flumioxazin & $900.9 \mathrm{aA}$ & $27.3 \mathrm{dC}$ & $152 \mathrm{cdB}$ & $159.4 \mathrm{cdB}$ \\
\hline T7 - Glyphosate+Ready-Mix (Imazethapyr \& Flumioxazin) & $52 \mathrm{~dB}$ & $49.8 \mathrm{~dB}$ & $205.2 \mathrm{cA}$ & $202.6 \mathrm{cA}$ \\
\hline
\end{tabular}

Uppercase letters compare sowing date for each control strategy and lowercase letters compare control strategy for each sowing date. DAA - Days after application of the weed-control strategies

Ceará coast. Furthermore, cultivation of the cowpea with weed control by a combination of glyphosate + flumioxazin at 15 DAA, was the only method of chemical control, among those being evaluated, which resulted in a productivity similar to that proposed by Paiva et al. (1990) for this cultivar, of $1,200 \mathrm{~kg} \mathrm{ha}^{-1}$. It can be inferred from these results that the weed-control strategy used on the crop resulted in selectivity and efficiency.

\section{CONCLUSIONS}

1. A mixture of the herbicides glyphosate + imazethapyr + flumioxazin caused phytotoxicity in the cowpea crop, placing limitations on the production components;

2. Considering weed-control in the area and the increase in value of the production components and crop productivity, the best strategies for weed control in the 
cowpea cv. Setentão are manual weeding with sowing after 10 days, as well as the application of a mixture of glyphosate + flumioxazin with sowing 15 days after application.

\section{REFERENCES}

ARAÚJO, M. E. B. Estratégias de irrigação deficitária no desempenho agronômico de cultivares de feijão-caupi no litoral cearense. 2014. 81 f. Dissertação (Mestrado em Engenharia Agrícola) - Centro de Ciências Agrárias, Universidade Federal do Ceará, Fortaleza, 2014.

FONTES, J. R. A.; GONÇALVES, J. R. P.; MORAIS, R. R. Tolerância do feijão-caupi ao herbicida oxadiazon. Pesquisa Agropecuária Tropical, v. 40, n. 1, p. 110-115, 2010.

FONTES, J. R. A.; OLIVEIRA, I. J.; GONÇALVES, J. R. P. Seletividade e eficácia de herbicidas para cultura do feijão-caupi. Revista Brasileira de Herbicidas, v. 12, n. 1, p. 47-55, 2013.

FREITAS, F. C. L. et al. Interferência de plantas daninhas na cultura do feijão-caupi. Planta Daninha, v. 27, n. 2, p. 241-247, 2009.

FREITAS, F. C. L. et al. Seletividade de herbicidas para a cultura do feijão-caupi. In: CONGRESSO BRASILEIRO DA CIÊNCIA DAS PLANTAS DANINHAS, 27., 2010, Ribeirão Preto. Anais... Ribeirão Preto: SBCPD, 2010. p. 1748-1752.

FREITAS, R. M. O. et al. Produção e qualidade de sementes de feijão-caupi em função de sistemas de plantio e estresse hídrico. Pesquisa Agropecuária Tropical, v. 43, n. 4, p. 370-376, 2013.

GRESSEL, J. Synergizing herbicides. Reviews of Weed Science, v. 5, n. 1, p. 49-82, 1990.

ISHAYA, V. B. et al. Effect of pre-emergence herbicide mixtures on cowpea (Vigna unguiculata (L.) Walp) at Samaru In Northern Nigeria. Crop Protection, v. 27, n. 7, p. 1105-1109, 2008.

LIMA, C. J. G. S. et al. Resposta do feijão caupi a salininidade da água de irrigação. Revista Verde Agroecologia Desenvolvimento Sustentável, v. 2, n. 2, p. 79-86, 2007.

LINHARES, C. M. de S. et al. Crescimento do feijão-caupi sob efeito dos herbicidas fomesafen e bentazon + imazamoz. Revista Caatinga, v. 27, n. 1, p. 41-49, 2014.

MACHADO, A. F. L. et al. Misturas de herbicidas no manejo de plantas daninhas na cultura do feijão. Planta Daninha, v. 24, n. 1, p. 107-114, 2006.
MONTEIRO, F. P. dos R. et al. Efeito de herbicidas na biomassa e nodulação do feijão-caupi inoculado com rizóbio. Revista Caatinga, v. 25, n. 3, p. 44-51, 2012.

OLIVEIRA, O. M. S. et al. Período de convivência das plantas daninhas com cultivares de feijão-caupi em várzea no Amazonas. Planta Daninha, v. 28, n. 3, p. 523-530; 2010.

PAIVA, J. B. et al. "Setentão" uma nova cultivar de feijão-decorda para o Estado do Ceará. Acta Botanica Brasilica, v. 4, n. 2, 1990.

PROCÓPIO, S. O. et al. Potencial de uso dos herbicidas chlorimuron-ethyl, imazethapyr e cloransulam-methyl na cultura do feijão. Planta Daninha, v. 27, n. 2, p. 327-336, 2009.

RODRIGUES, C. de F. et al. Sistema de consórcio do girassol, feijão-de-corda e amendoim em séries de substituição. Revista Brasileira de Agricultura Irrigada, v. 8, n. 3, p. 256-269, 2014.

SANTOS, J. A. S. et al. Desempenho agronômico e divergência genética entre genótipos de feijão-caupi cultivados no ecótono Cerrado/Pantanal. Bragantia, v. 73, n. 4, p. 377-382, 2014.

SIKKEMA, P. H. et al. Tolerance of otebo bean (Phaseolus vulgaris) to new herbicides in Ontario. Weed Technology, v. 20, n. 4, p. 862-866, 2006

SILVA, A. A.; VIVIAN, R.; OLIVEIRA JUNIOR, R. S. O. Herbicidas: comportamento no solo. In: SILVA, A. A.; SILVA, J. F. (Ed.). Tópicos em manejo de plantas daninhas. Viçosa, MG: UFV, 2007. cap. 5, p. 189-248.

SILVA, F. de A. S.; AZEVEDO, C. A. V. de. Principal components analysis in the software Assistat-Statistical Attendance. In: WORLD CONGRESS ON COMPUTERS IN AGRICULTURE, 7., Reno. Proceedings... Reno, Nevada: American Society of Agricultural and Biological Engineers, 2009.

SILVA, J. F.; ALBERTINO, S. M. F. Manejo de plantas daninhas. In: ZILLI, J. E.; VILARINHO, A. A.; ALVES, J. M. A. A cultura do feijão-caupi na Amazônia brasileira. Boa Vista: Embrapa Roraima, 2009. p. 223-243.

SILVA, K. S. et al. Eficiência de herbicidas para a cultura do feijão-caupi. Revista Planta Daninha, v. 32, n. 1, p. 197-205, 2014.

VIDAL, R. A. et al. Initialism: a new term to describe the first mechanism of negative interaction between weeds and crops. Journal of Plant Diseases and Protection, v. 21, n. 1, p. 95-98. 2008. 